
легких новорожденных морских свинок свободными радикалами

1 - Учреждение образования "Белорусский государственный медицинский университет": 220116, Республика Беларусь, Минск, пр-т Дзержинского, 83;

2 - Учреждение здравоохранения "Городское клиническое патологоанатомическое бюро" г. Минска: 220116, Республика Беларусь, Минск, ул. Семашко, 8, корп. 8

\title{
A.D.Taganovich, S.L.Anishchenko, I.L.Kotovich, Zh.A.Rutkovskaya Morphological basis of lung injury by free radicals and the treatment in newborn guinea pigs
}

\begin{abstract}
Summary
Structural and morphometrical lung changes in guinea pigs exposed to hyperoxia or induced reactive oxygen species (ROS) production during 14 days alone or under inhalations of $\mathrm{N}$-acetylcysteine (in water solution or built-in multilayered liposomes), $\alpha$-tocopherol or retinol have been studied. We established that induced ROS production in the lungs was associated with structural change of the lung tissue compatible with that in animals exposed to hyperoxia. Most typical changes associated with hyperoxia and induced ROS production were reduction in the alveolar intercept area and increase in the total area of the alveolar space and intrapulmonary vessel lumen. All the therapy regimens effectively prevented hyperoxiainduced changes of the alveolar space / interstitium relationship but were fail to prevent the dilation of the intrapulmonary vessels. The inhalation of $\mathrm{N}$-acetylcysteine seemed to be the most effective treatment.

Key words: bronchopulmonary dysplasia, hyperoxia, reactive oxygen species, antioxidants, morphology and morphometry of the lungs.
\end{abstract}

\section{Резюме}

Изучены морфологические и морфометрические характеристики легких новорожденных морских свинок, подвергнутых гипероксии или индукции образования активных форм кислорода (АФК) в течение 14 суток, а также подвергнутых гипероксии на фоне ингаляционного введения в легкие $\mathrm{N}$-ацетилцистеина (NAC) (в водорастворимой и встроенной в многослойные липосомы форме), $\alpha$-токоферола или ретинола. Установлено, что индукция образования свободных радикалов в легких без воздействия гипероксии сопровождается структурным изменением легочной ткани, сходным с таковым на 14-е сутки гипероксии. Суммарная площадь просвета альвеол, а также суммарная площадь просвета интраорганных сосудов артериального типа были сушественно выше, а плошадь межальвеолярных перегородок и эпителия альвеол - меньше, чем у контрольных животных. Всеми использованными способами коррекции продемонстрирована эффективность в предотвращении развития структурных изменений при изолированном воздействии гипероксии. Однако введение в легкие водного аэрозоля NAC, согласно полученным данным, было более предпочтительно.

Ключевые слова: бронхолегочная дисплазия, гипероксия, активные формы кислорода, антиоксиданты, морфология и морфометрия легких.

Бронхолегочная дисплазия (БЛД) представляет собой хроническое легочное заболевание, которое развивается у недоношенных детей, получающих терапию кислородом путем вентиляции легких положительным давлением [1]. Для БЛД характерны снижение эластичности легочной ткани, увеличение динамического сопротивления дыхательных путей, длинная временна́я константа, увеличение анатомического "мертвого" пространства и функциональной остаточной емкости легких (вследствие эмфиземы), аномальное вентиляционно-перфузионное соотношение, повышенная реактивность бронхов, обструкция бронхов и, как следствие - нарушенный газообмен, низкий дыхательный объем, увеличение частоты дыхания, низкое парциальное давление $\mathrm{O}_{2}$, накопление $\mathrm{CO}_{2}$ [2].

Вероятность развития БЛД зависит от гестационного возраста и массы тела новорожденного. Чем меньше гестационный возраст и масса тела при рож- дении, тем чаще у детей развивается БЛД [1, 2]. При этом в качестве этиопатогенетических факторов выступают высокая концентрация кислорода, барои волюмотравма при проведении искусственной вентиляции легких (ИВЛ), отек легочной ткани вследствие избыточного введения в организм жидкости, незрелость сурфактантной системы, нарушение баланса образования активных форм кислорода (АФК) и их катаболизма [3].

Экспериментальные исследования дают уникальную возможность изучения молекулярных событий, происходящих в легочной ткани на этапах формирования БЛД, отработки и обоснования новых методов лечения этой патологии. Однако при моделировании БЛД невозможно полное воспроизведение условий формирования этого состояния у человека: во-первых, экспериментальные исследования проводились на разных животных (мыши, крысы, обезьяны и др.), которые выдерживались в течение различного 
времени при разной концентрации кислорода во вдыхаемом воздухе [4-6]. Во-вторых, в большинстве моделей используются новорожденные животные, которые родились в срок, в то время как в клинической практике БЛД чаще развивается у недоношенных новорожденных, находившихся на ИВЛ, т. е. в расчет должна приниматься различная степень незрелости легочной ткани, при которой изучается формирование БЛД.

Приведенные обстоятельства должны учитываться при проведении экспериментальных исследований. В частности, обязательными являются изучение и контроль морфологических изменений в легочной ткани. Только обнаружение структурных изменений, сходных с имеющимися при БЛД, дает основание причислить любые другие находки к свойственным именно для этой патологии.

При создании метода профилактики и лечения БЛД использовалась экспериментальная модель, в основе которой лежала гипотеза о ведущей роли гипероксии в развитии повреждения легких новорожденных. Были выявлены закономерности структурных изменений в легких новорожденных морских свинок, подвергнутых воздействию гипероксии в течение 14 суток. Они были аналогичны тем, которые имеют место при БЛД [7].

Принято считать, что ведущая роль в патогенетическом воздействии гипероксии принадлежит свободнорадикальному окислению [8]. Аргументами в пользу такого предположения послужили данные биохимических исследований, не позволившие однозначно судить о причастности свободных радикалов к развитию структурных изменений легких. Морфологическое исследование могло бы восполнить имеющийся недостаток доказательств.

Целью данного экспериментального исследования явилось сравнение морфологических изменений, индуцированных свободнорадикальным окислением и гипероксией в легких у новорожденных морских свинок, а также характеристика легких у экспериментальных животных, подвергнутых гипероксии на фоне ингаляционного введения антиоксидантов.

\section{Материалы и методы}

Эксперимент проводился с использованием новорожденных морских свинок, находившихся на стандартном рационе вивария УО "БГМУ". Были сформированы 7 групп наблюдения: Контроль, Гипероксия 14 суток, Индукция АФК, Коррекция 1, Коррекция 2, Коррекция 3, Коррекция 4. Каждая экспериментальная группа состояла из 4-5 животных.

Контроль. Контрольные животные в течение 14 суток дышали обычным воздухом.

Гипероксия 14 суток. Животные в течение суток после рождения помещались в плексигласовую камеру, в которой в течение всего времени инкубации поддерживалась концентрация кислорода $\geq 70 \%$ (температура $-20-25^{\circ} \mathrm{C}$, относительная влажность 50-80\%). Концентрация кислорода в камере конт- ролировалась с помощью анализатора кислорода ПГК-06-100Р (3АО "Инсовт", Россия). Длительность инкубации в условиях гипероксии составляла 14 суток, т. к. именно в эти сроки воздействия гипероксии ранее были выявлены наиболее выраженные морфологические изменения в легких.

Индукция АФК. Идея моделирования свободнорадикального повреждения легких in vivo была заимствована из метода индукции образования АФК, описанного для применения in vitro $[9,10]$. В основе лежит общеизвестная реакция Фентона $(1,2)$ и способность аскорбата восстанавливать железо с образованием $\mathrm{Fe}_{2}{ }^{+}$(3) [12]:

$$
\begin{aligned}
& \mathrm{Fe}^{2+}+\mathrm{H}_{2} \mathrm{O}_{2}>\mathrm{Fe}^{3+}+\mathrm{OH}+\mathrm{OH}^{-}, \\
& \mathrm{Fe}^{3+}+\mathrm{H}_{2} \mathrm{O}_{2}>\mathrm{Fe}^{2+}+\mathrm{OOH}+\mathrm{H}^{+}, \\
& 2 \mathrm{Fe}^{3+}+\text { аскорбат }>2 \mathrm{Fe}^{2+}+\text { дегидроаскорбат. }
\end{aligned}
$$

Индукционная смесь, содержащая $\mathrm{FeSO}_{4}$ (0,2 ммоль / л; 0,4 мг / кг), аскорбиновую кислоту (2 ммоль / л, 2,5 мг / кг) и натрий-фосфатный буфер $(0,1$ моль / л) с ЭДТА $(0,1$ ммоль / л) $(\mathrm{pH}=7,4)$, готовилась непосредственно перед использованием и вводилась ингаляционно с помощью компрессорного небулайзера. Продолжительность 1 ингаляции составляла в среднем 30 мин, общее число ингаляций - 14 (ежедневно в течение 14 дней).

Возможность коррекции изменений в легких, развивающихся вследствие гипероксии, изучалась с помощью ингаляционного введения антиоксидантов: 20\%-ного раствора для ингаляций $\mathrm{N}$-ацетилцистеина (NAC) (Белмедпрепараты, Беларусь), $\alpha$-токоферола, all-trans-ретинола, all-trans-ретиноевой кислоты (Sigma, США). Ингаляции проводились с использованием компрессорного небулайзера (Omron, Китай) 1 раз в 2 дня, всего 7 раз в течение 14 суток воздействия на животных гипероксии.

Коррекция 1. В ингаляционной смеси содержался NAC (250 мг / кг) и натрий-фосфатный буфер (0,1 моль / л) с ЭДТА (0,1 ммоль / л), $\mathrm{pH}=7,4$.

Коррекция 2. Для ингаляций использовалась свежеприготовленная смесь мультиламеллярных липосом, содержащих NAC (250 мг / кг), 50 мг / кг L- $\alpha$-дипальмитоилфосфатидилхолин (ДПФХ) (Sigma, США) и натрий-фосфатный буфер (0,1 моль / л) с ЭДТА $(0,1$ ммоль / л), $\mathrm{pH}=7,4$. Для приготовления липосом спиртовой раствор ДПФХ (40 мг / мл) упаривался на вакуумном роторном испарителе до получения сухой липидной пленки при температуре $38 \pm 2{ }^{\circ} \mathrm{C}$. K полученной пленке добавлялся 1 мл 20\%-ного раствора NAC для ингаляций (Белмедпрепараты, Беларусь), затем смесь встряхивалась в миксере Maxi-Mix 1 (Thermolyne, США) до образования однородной дисперсии в течение 10 мин. Диспергирование велось при температуре $60{ }^{\circ} \mathrm{C}$, что выше температуры фазовых переходов липидов, формирующих липосомальную мембрану. Полученные липосомы инкубировались в течение 1 ч при $40{ }^{\circ} \mathrm{C}$ и использовались для приготовления ингаляционной смеси.

Коррекция 3. Для ингаляций использовалась свежеприготовленная смесь мультиламеллярных липосом, содержащих $\alpha$-токоферол (12,5 мг / кг), ДПФХ 
(44 мг / кг) и натрий-фосфатный буфер (0,1 моль / л) с ЭДТА (0,1 ммоль / л), $\mathrm{pH}=7,4$. Для приготовления липосом в спиртовой раствор ДПФХ (35 мг / мл) добавлялся хлороформный раствор $\alpha$-токоферола (10 мг / мл), затем полученная смесь упаривалась при температуре $38 \pm 2{ }^{\circ} \mathrm{C}$ на вакуумном роторном испарителе до получения сухой липидной пленки. После добавления к полученной пленке 1 мл натрий-фосфатного буфера (0,1 моль / л) с ЭДТА (0,1 ммоль / л), $\mathrm{pH}=7,4$ проводилось диспергирование.

Коррекция 4. Для ингаляций использовалась свежеприготовленная смесь мультиламеллярных липосом, содержащих ретинол (6 мг / кг), ретиноевую кислоту (0,6 мг / кг), ДПФХ (44 мг / кг) и натрийфосфатный буфер (0,1 моль / л) с ЭДТА (0,1 ммоль / л), $\mathrm{pH}=7,4$. Для приготовления липосом спиртовой раствор, содержащий ДПФХ (35 мг / мл), ретинол (4,8 мг / мл) и ретиноевую кислоту (0,48 мг / мл), упаривался на вакуумном роторном испарителе до получения сухой липидной пленки при температуре $38 \pm 2{ }^{\circ} \mathrm{C}$. К полученной пленке добавлялся 1 мл натрий-фосфатного буфера (0,1 моль / л) с ЭДТА $(0,1$ ммоль / л), $\mathrm{pH}=7,4$. Диспергирование проводилось указанным способом.

Методика приготовления мультиламеллярных липосом, используемая в группах коррекции 2-4, является общепризнанной, размер получаемых частиц составляет 0,5-10 мкм [11].

Все животные выводились из эксперимента путем внутрибрюшинной инъекции дозы тиопентала натрия (15 мг / кг), затем у них выделялись легкие для исследования.

Легкие разрезались в горизонтальной плоскости на тканевые блоки с интервалом 3 мм. Материал фиксировался в 10\%-ном растворе нейтрального формалина, проводился через спирты возрастающей концентрации, хлороформ и заливался в парафин. Гистологические срезы толщиной 5-7 мкм окрашивались гематоксилином и эозином по Ван Гизону и исследовались при помощи светового микроскопа Axioscop 40 (Karl Zeiss, ФРГ).

Для оценки количественных показателей состояния легочной ткани проводилась фотосъемка гистологических препаратов цифровой камерой DFC 425 (Leica, ФРГ), подключенной к световому микроскопу DM 2500 (Leica, ФРГ) при 200- и 400-кратном увеличении. Формат изображения составил $2592 \times$ 1944 и $3888 \times 2916$ пикселей соответственно. Полученные цифровые фотографии импортировались в электронный анализатор изображения - программу Photo M 1.31 [13], с помощью которой после калибровки для соответствующего увеличения обводились курсором по контуру области искомых структур. Указанные области анализировались с помощью компьютерной программы и пересчитывались в метрические единицы. Таким образом измерялись суммарные площади просвета альвеол, межальвеолярных перегородок и эпителия альвеол и просвета сосудов артериального типа в поле зрения.

В каждом наблюдении для анализа было использовано $\geq 10$ неперекрывающихся между собой полей зрения. Результаты измерения экспортировались в Microsoft Excel.

Количественные данные, распределение которых было отличным от нормального, описывались при помощи медианы, 25 и 75 \% процентилей. Сравнение 2 выборок проводилось при помощи непараметрического критерия Манна-Уитни (U-тест). Статистически значимым считался результат, если вероятность отвергнуть нулевую гипотезу об отсутствии различий не превышала $5 \%(p<0,05)$.

\section{Результаты}

В контрольной группе слизистая оболочка бронхов и бронхиол имела фестончатые очертания, наблюдалась относительно равномерная воздушность легочной ткани. Менее воздушная легочная ткань отмечена в перибронхиальных отделах, более воздушная в периферических отделах легких, преимущественно субплевральных. У интраорганных артерий и артериол имелись толстые стенки и небольшой округлый или щелевидный просвет.

У животных, подвергнутых гипероксии, легочная ткань выглядела более расправленной, воздушной, с очажками в виде групп растянутых альвеол с истонченными стенками в субплевральных отделах и перибронхиальных участках легких. В участках мелкоочаговых ателектазов в отдельных альвеолах наблюдались небольшие скопления альвеолярных макрофагов. Отмечались десквамативные изменения респираторного эпителия бронхов, расширение просвета сосудов артериального типа и умеренное полнокровие капилляров межальвеолярных перегородок (рис. 1А). В строме легких, преимущественно периваскулярно и перибронхиально, определялись мелкоочаговые инфильтраты из лимфоцитов и сегментоядерных лейкоцитов.

В условиях индукции образования свободных радикалов в легких без воздействия гипероксии изменение легочной ткани было сходным с таковым на 14-е сутки гипероксии (рис. 2). Однако легочная паренхима представляла собой более пеструю картину избыточно растянутых альвеол, чередующихся с участками дистелектаза и ателектаза (рис. 2В). Очаговое расширение просвета альвеол с истончением межальвеолярных перегородок в субплевральных отделах было более выраженным, чем у животных на 14-е сутки гипероксии (рис. 2А). Наряду с неравномерной воздушностью легочной ткани отмечались дистрофические изменения и частичная десквамация бронхиального эпителия (рис. 2Б), расширение просвета бронхиол (рис. 2В), выраженное полнокровие межальвеолярных перегородок, чаще встречались скопления макрофагов в просвете альвеол (рис. $2 \Gamma$ ).

Данные морфометрии показывают, что суммарная площадь просвета альвеол в гистологических срезах легких животных, находившихся в условиях индукции свободнорадикального повреждения, а также суммарная площадь просвета интраорганных сосудов артериального типа, как и после гипероксии 

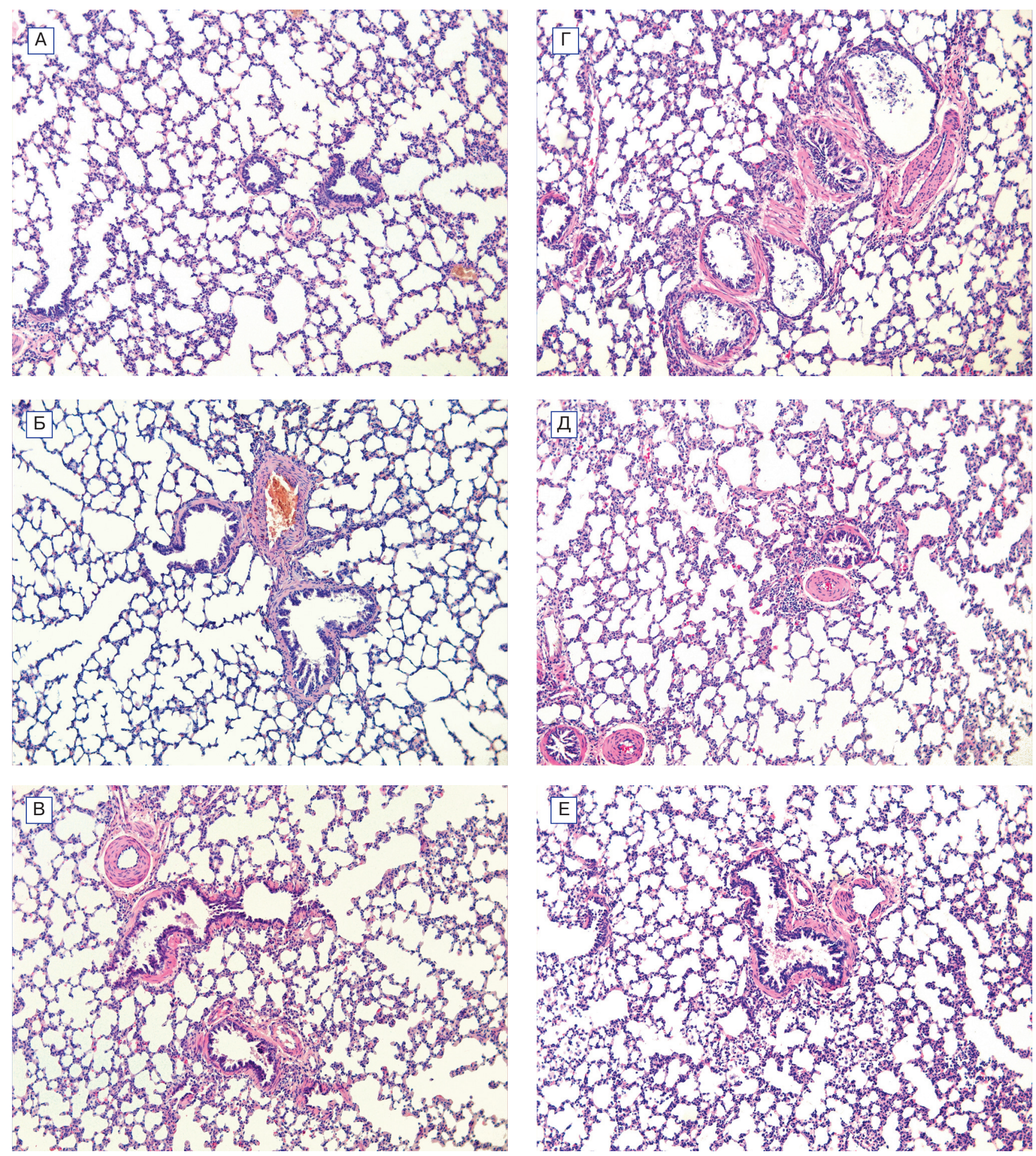

Рис. 1. Морфологическая картина легких у животных опытных групп: А - через 14 суток гипероксии; Б - Индукция АФК; В - Коррекция 1 ; Г - Коррекция 2; Д - Коррекция 3 ; Е - Коррекция 4; окраска гематоксилином и эозином; $\times 100$

в течение 14 суток, были существенно выше, чем у животных контрольной группы (см. таблицу). Площадь же межальвеолярных перегородок и эпителия альвеол у них была статистически достоверно меньше, чем у животных группы контроля.

На 14-е сутки наблюдения в легких экспериментальных животных группы Коррекция 1 фестончатые очертания слизистой оболочки мелких бронхов и бронхиол сохранялись, наблюдались слабовыраженные десквамативные изменения бронхиального эпителия, небольшое количество секрета в просвете бронхов, относительно равномерная воздушность легочной ткани, единичные макрофаги в просвете альвеол. Преобладали артерии и артериолы с хорошо выраженной мышечной оболочкой стенки, небольшим просветом округлой или овальной формы; межальвеолярные перегородки были умеренно полнокровны (см. рис. 1В). Минимальные воспалительные изменения в виде мелкоочаговых инфильтратов из эозинофилов и лимфоцитов выявлялись преимущественно в периваскулярных и перибронхиальных пространствах. 
Морфометрические показатели легких новорожденных морских свинок, подвергнутых гипероксии, свободнорадикальному повреждению и воздействию антиоксидантов

\begin{tabular}{|c|c|c|c|c|c|c|c|c|c|}
\hline \multirow{3}{*}{$\begin{array}{l}\text { Группа } \\
\text { животных }\end{array}$} & \multicolumn{9}{|c|}{ Суммарная площадь } \\
\hline & \multicolumn{3}{|c|}{ просвета альвеол } & \multicolumn{3}{|c|}{$\begin{array}{c}\text { межальвеолярных перегородок } \\
\text { и эпителия альвеол }\end{array}$} & \multicolumn{3}{|c|}{ просвета мелких артерий и артериол } \\
\hline & мкм $^{2}$ & $\%$ & $p$ & мкм $^{2}$ & $\%$ & $p$ & мKM $^{2}$ & $\%$ & $p$ \\
\hline Контроль & $\begin{array}{c}11059,4 \\
(10741,7 ; 11362,7)\end{array}$ & 52,50 & 0,040 & $\begin{array}{c}10004,5 \\
(9701,2 ; 10322,1)\end{array}$ & 47,50 & 0,040 & $\begin{array}{c}20,7 \\
(13,8 ; 32,0)\end{array}$ & 0,2 & 0,001 \\
\hline $\begin{array}{l}\text { Гипероксия } \\
14 \text { суток }\end{array}$ & $\begin{array}{c}12528,2 \\
(12103,7 ; 12872,7)\end{array}$ & 59,50 & & $\begin{array}{c}8535,7 \\
(8191,1 ; 8960,1)\end{array}$ & 40,50 & & $\begin{array}{c}104,3 \\
(81,5 ; 155,9)\end{array}$ & 1,1 & \\
\hline $\begin{array}{l}\text { Индукция } \\
\text { АФК }\end{array}$ & $\begin{array}{c}12443,63 \\
(11709,1 ; 12924,03)\end{array}$ & 59,07 & 0,017 & $\begin{array}{c}8620,22 \\
(8139,8 ; 9354,875)\end{array}$ & 40,90 & 0,017 & $\begin{array}{c}77,2 \\
(57,6 ; 129,8)\end{array}$ & 0,8 & 0,001 \\
\hline Коррекция 1 & $\begin{array}{c}10443,57^{*}, " \\
(9512,6 ; 10918,3)\end{array}$ & 49,58 & 0,212 & $\begin{array}{c}10620,29 ; \\
(10145,55 ; 11551,2)\end{array}$ & 50,42 & 0,212 & $\begin{array}{c}68,6 \\
(55,2 ; 85,7)^{*}\end{array}$ & 0,7 & 0,001 \\
\hline Коррекция 2 & $\begin{array}{c}11031,34^{*},{ }^{* *} \\
(10527,9 ; 11329,64)\end{array}$ & 52,37 & 0,791 & $\begin{array}{c}10032,51^{*,{ }^{* *}} \\
(9734,2 ; 10535,96)\end{array}$ & 47,63 & 0,791 & $\begin{array}{c}110,5 \\
(71,4 ; 122,4)\end{array}$ & 1,16 & $<0,001$ \\
\hline Коррекция 3 & $\begin{array}{c}10765,17^{*, * *} \\
(10062,9 ; 11478,4)\end{array}$ & 51,10 & 0,473 & $\begin{array}{c}10298,68^{*}, * * \\
(9585,42 ; 11000,9)\end{array}$ & 48,9 & 0,473 & $\begin{array}{c}87,6 \\
(47,6 ; 112,4)\end{array}$ & 0,9 & $<0,001$ \\
\hline Коррекция 4 & $\begin{array}{c}11002,46, ; * \\
(10220,29 ; 11374,78)\end{array}$ & 52,23 & 0,734 & $\begin{array}{c}10061,39 *, * \\
(9689,075 ; 11026,85)\end{array}$ & 47,77 & 0,734 & $\begin{array}{c}169,5 \\
(113,3 ; 181,9) 1-4,3-4\end{array}$ & 1,78 & $<0,001$ \\
\hline
\end{tabular}

Примечание: в столбце "\%" приведено среднее арифметическое относительных площадей измеряемых параметров (по отношению к площади поля зрения); во всех экспериментальных группах число анализируемых срезов - 10; $p$ - результат U-теста по сравнению с группой контроля; статистически достоверная разница по сравнению со следующими группами: * - Гипероксия 14 суток; ** - Индукция АФК; 1-4 - Коррекция 1; 3-4 - Коррекция 3.
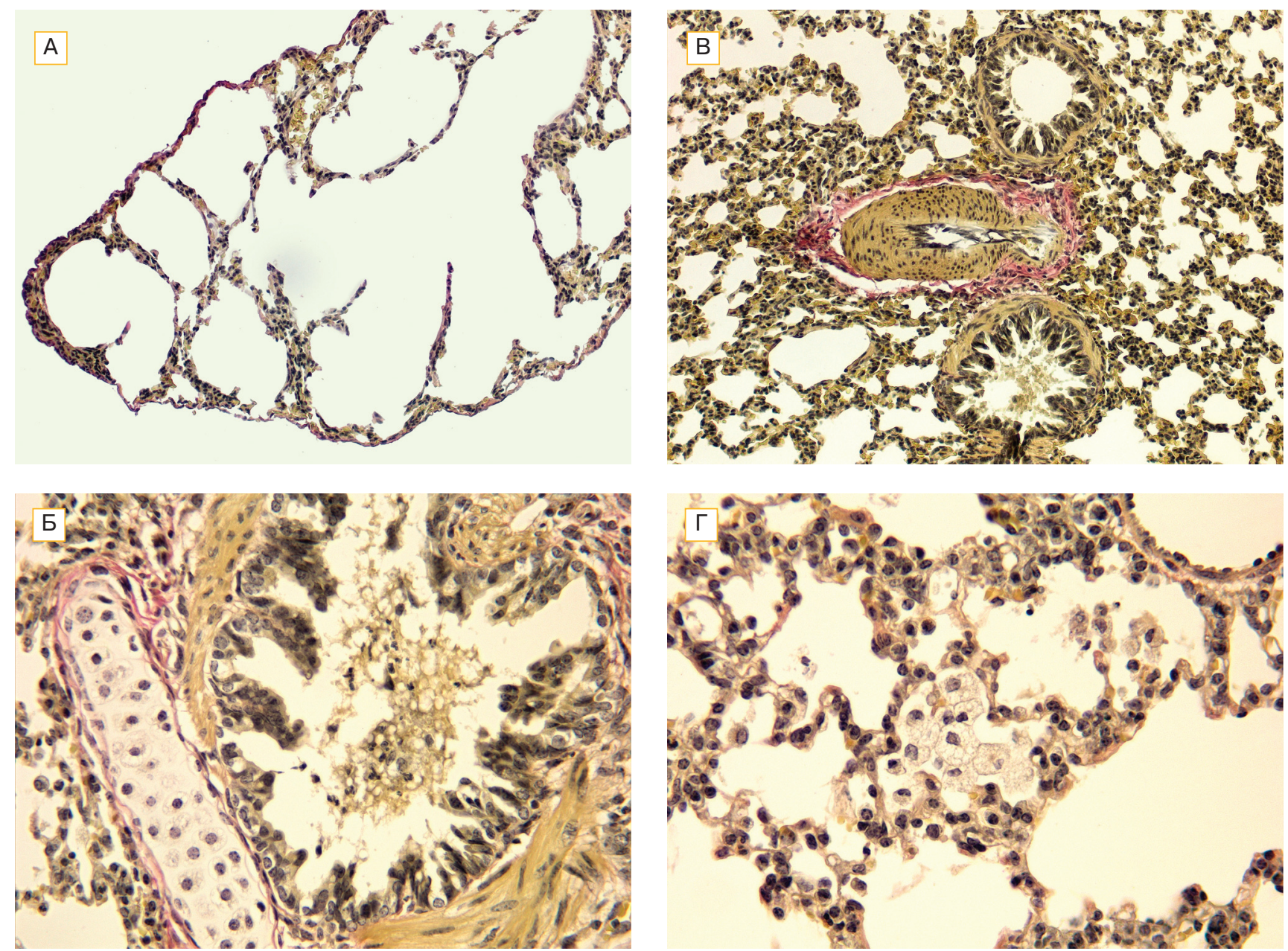

Рис. 2. Морфологические изменения в легких у новорожденных морских свинок, вызванные индукцией образования АФК в течение 14 суток: А - расширение просвета альвеол в субплевральных отделах с истончением и разрывом межальвеолярных перегородок; Б - секрет и сегментоядерные лейкоциты в просвете бронха; В - неравномерная воздушность легочной ткани; Г - альвеолярные макрофаги в просвете альвеол; окраска по Ван-Гизону; А, В - × 200; Б, Г - × 400 
У животных группы Коррекция 2 в легких отмечались выраженная эктазия бронхиол и мелких бронхов, содержащих в просвете десквамированный эпителий, слизь и лейкоциты, неравномерная воздушность легочной ткани с чередованием участков ателектаза, дистелектаза и очагового расширения просвета альвеол с истончением межальвеолярных перегородок, наличием небольших скоплений макрофагов и сегментоядерных лейкоцитов в просвете отдельных альвеол. Просвет сосудов артериального типа был умеренно расширен (см. рис. 1Г). В отечных периваскулярных и перибронхиальных пространствах встречались воспалительные инфильтраты, представленные преимушественно мононуклеарными клеточными элементами.

У животных группы Коррекция 3 морфологические изменения в легких были сходными с описанными в группе Коррекция 2. Отличительными особенностями были менее заметная эктазия бронхиол и мелких бронхов, а также умеренно выраженные воспалительные изменения в легочной ткани (см. рис. 1Д).

Морфологические изменения в легких у экспериментальных животных группы Коррекция 4 были во многом сходны с описанными в группах Коррекции 2 и 3 (см. рис. 1Е). Основным отличием, выявленным при светооптическом исследовании, были более значительные скопления макрофагов в просвете альвеол.

Суммарная площадь просвета альвеол в легких животных при всех способах коррекции гипероксии существенно уменьшилась по сравнению с животными, подвергнутыми гипероксии без коррекции оксидантно-антиоксидантного статуса или индукции образования АФК в легких, а площадь межальвеолярных перегородок и эпителия альвеол увеличилась. При сравнении с контрольной группой различий указанных морфометрических показателей не отмечено (см. таблицу). При сравнительном анализе этих показателей легких между группами с различными видами коррекции статистически достоверные различия отсутствовали.

При окраске по Ван-Гизону не выявлено увеличения содержания коллагеновых волокон в строме легких у всех опытных животных по сравнению с контролем.

Следует отметить, что реакция сосудов артериального типа была отмечена во всех опытных группах по сравнению с контролем. Эти изменения на светооптическом уровне характеризовались эктазией просвета сосудов артериального типа, при морфометрическом исследовании - достоверным увеличением суммарной площади просвета артерий и артериол (см. таблицу). Во всех опытных группах изменения носили однонаправленный характер, но различную (в количественном отношении) степень выраженности. По сравнению с группой животных после гипероксии в течение 14 суток суммарная площадь просвета артерий была достоверно меньше только в группе Коррекция 1. Во всех остальных опытных группах (Индукция АФК, Коррекция 2-4) достоверные различия отсутствовали. При сравнительном анализе наиболее выраженная эктазия просвета сосудов отмечалась в группе Коррекция 4. Этот показатель был достоверно выше, чем в группах Коррекция 1 и 3.

\section{Результаты и обсуждение}

Изменения, вызываемые воздействием гипероксии, принято связывать со стимуляцией продукции свободных радикалов кислорода и окислительным повреждением клеток и молекулярных структур легких. Убедительные доказательства взаимосвязи 2 явлений (усиления генерации АФК и развития структурных изменений в легких, характерных для БЛД) отсутствуют. Чтобы подтвердить наличие такой связи, требовалось изучить характер изменений, развивающихся в легких в условиях эксперимента, моделирующего свободнорадикальное повреждение без воздействия гипероксии, и сравнить их с таковыми при гипероксии.

В данном исследовании для стимуляции процессов пероксидации использовалась индукционная смесь $\mathrm{Fe}^{2+}$ - аскорбат (0,2 и 2 ммоль / л соответственно). Данная смесь неоднократно применялась в экспериментах на различных типах клеток в качестве индуктора генерации свободных радикалов [9, 10], однако по имеющимся данным, in vivo для стимуляции повреждения легких ранее не использовалась. В настоящем исследовании изменения, выявленные в легких при эксперименте, моделирующем индукцию АФК in vivo с использованием системы $\mathrm{Fe}^{2+}$ - аскорбат, оказались весьма сходны с теми, которые были описаны ранее при гипероксии (по данным литературы) [6, 7]. Выявлено увеличение суммарной площади просвета альвеол и уменьшение площади межальвеолярных перегородок и эпителия альвеол. Изменения в легочной ткани на 14-е сутки гипероксии имели аналогичный характер, что позволяет считать оправданным использование антиоксидантов для предотвращения или ослабления развития патологических изменений в легких в условиях гипероксии.

В литературе встречаются результаты исследований, в ходе которых неоднократно предпринимались попытки использовать антиоксиданты в лекарственной терапии БЛД. Большей частью они применялись у новорожденных детей [14], однако есть и экспериментальные исследования [5, 15]. Изучалась эффективность внутримышечного, внутривенного или перорального введения различных препаратов ( $\alpha$-токоферол, ретинол, NAC, аскорбиновая кислота, супероксиддисмутаза) при относительно непродолжительных сроках воздействия гипероксии ( $\leq 4$ суток). Как правило, не удавалось достичь существенного уменьшения выраженности изменений в легких. При этом важным фактором, лимитирующим использование парентерального способа введения препаратов у недоношенных новорожденных, является его инвазивность. Следует принять во внимание и незрелость систем доставки 
ряда веществ, в частности липофильных, из крови в легкие у недоношенных детей [16].

Ингаляционный путь введения антиоксидантов более предпочтителен в связи с тем, что он обеспечивает целенаправленную доставку всей дозы вводимого препарата непосредственно в легкие. Использовались традиционные антиоксиданты ( $\alpha$-токоферол, ретинол, NAC). Представляет интерес выбор формы препарата - водный раствор (для NAC) либо липосомальная суспензия (для NAC и жирорастворимых витаминов). В случае жирорастворимых витаминов липосомы - наиболее адекватная форма доставки ингаляционным путем in vivo вследствие невозможности использования токсичных неполярных растворителей.

По данным исследования, ингаляционное введение препаратов дает обнадеживающие результаты. У всех использованных антиоксидантов (как в водорастворимой, так и в липосомальной форме) продемонстрирована хорошо заметная способность подавлять развитие патологических изменений в легочной ткани, вызванных гипероксией. Об этом свидетельствуют данные морфометрического анализа: достоверное уменьшение до контрольных значений суммарной площади просвета альвеол и увеличение их количества, увеличение площади межальвеолярных перегородок и эпителия альвеол.

Наряду с таким позитивным эффектом следует отметить, что ни один из примененных способов коррекции не смог предотвратить значительного увеличения площади просвета артериол, вызванного гипероксией. Лишь ингаляционное введение водного раствора NAC экспериментальным животным сопровождалось существенно меньшей выраженностью этого увеличения, которое, однако, значительно ( $\geq 3$ раза) превышало контрольный уровень.

На светооптическом уровне обращали на себя внимание отдельные особенности эффектов от введения различных форм и видов антиоксидантов усиление десквамации бронхиального эпителия (Коррекция 2), более выраженная воспалительная реакция в легочной ткани (Коррекция 3), скопление макрофагов в просвете альвеол (Коррекция 4). Суммарная площадь просвета артериол в срезах легких из группы Коррекция 4 выросла еще больше, чем в группе Гипероксия 14 суток и была значительно выше, чем группах Коррекция 1 и 3.

Все использованные способы коррекции в целом оказались результативными; продемонстрирована эффективность в предотвращении развития структурных нарушений при изолированном воздействии гипероксии. С одной стороны, это свидетельствует о правильности выбора препаратов для коррекции (действие которых направлено на уменьшение образования свободных радикалов в легочной ткани) и способа введения веществ. С другой стороны, каждый из них имеет свой механизм и область антиоксидантного действия (NAC является водорастворимым, токоферол и ретинол - жирорастворимы). Возможно, поэтому под влиянием этих антиоксидантов и были отмечены указанные особенности.
В сравнительном аспекте полученные данные свидетельствуют о том, что введение в легкие водного аэрозоля NAC более предпочтительно в качестве способа коррекции.

\section{Заключение}

В результате проведенного исследования показана ведущая роль свободнорадикального окисления в повреждении легочной ткани, индуцированном длительным воздействием гипероксии. Поскольку условия эксперимента были приближены к условиям выхаживания недоношенных новорожденных с использованием длительной механической вентиляции легких, рекомендована разработка методов и средств, подавляющих свободнорадикальное окисление в этих условиях. Предложена оригинальная неинвазивная форма введения антиоксидантов в легкие для этих целей, существенно уменьшающая патологические изменения в структуре легочной ткани.

\section{Литература}

1. Шишко Г.А., Устинович Ю.А. Современные подходы к ранней диагностике и лечению бронхолегочной дисплазии: Учебно-методическое пособие для врачей. Минск: БелМАПО; 2006.

2. Velten M., Heyob K.M., Rogers L.K. et al. Deficits in lung alveolarization and function after systemic maternal inflammation and neonatal hyperoxia exposure. J. Appl. Physiol. 2010; 108: 1347-1356.

3. Hayes D., Feola D.J., Murphy B.S. et al. Pathogenesis of bronchopulmonary dysplasia. Respiration 2010; 79: $425-436$

4. Tang F.G., Yue S.J., Luo Z.Q. et al. Role of N-methyl-Daspartate receptor in hyperoxia-induced lung injury. Pediatr. Pulmonol. 2005; 40: 437-444.

5. James M.L., Ross A.C., Bulger A. et al. Vitamin A and retinoic acid act synergistically to increase lung retinyl esters during normoxia and reduce hyperoxic lung injury in newborn mice. Pediatr. Res. 2010; 67: 591-597.

6. Deng Hui, Manson S.N., Auten R.L. Lung inflammation in hyperoxia can be prevented by antichemokine treatment in newborn rats. Am. J. Respir. Crit. Care Med. 2000; 162: 2316-2323.

7. Таганович А.Д., Анищенко С.Л., Котович И.Л. и др. Структурные изменения в легких новорожденных морских свинок при гипероксии. Весці Нацыянальнай акадэміi Навук Беларусі. Сер. мед. навук 2013; 1: 71-77.

8. Auten R.L., Davis J.M. Oxygen toxicity and reactive oxygen species: the devil is in the details. Pediatr. Res. 2009; 66: $121-127$

9. Courtois F., Seidman E.G., Delvin E. et al. Membrane peroxidation by lipopolysaccharide and iron-ascorbate adversely affects Caco-2 cell function: beneficial role of butyric acid. Am. J. Clin. Nutr. 2003; 77: 744-750.

10. Marcil V., Lavoie J.C., Emonnot L. et al. Analysis of the effects of iron and vitamin $\mathrm{C}$ co-supplementation on oxidative damage, antioxidant response and inflammation in THP-1 macrophages. Clin. Biochem. 2011; 44: 873-883.

11. Dua J.S., Rana A.C., Bhandari A.K. Liposome: methods of preparation and applications. Int. J. Pharm. Stud. Res. 2012; 3: 14-20. 
12. Владимиров Ю.А., Проскурина Е.В. Свободные радикалы и клеточная хемилюминесценция. Успехи биол. химии 2009; 49: 341-388.

13. Cernigovskii, 2004; электронный ресурс: http://softok.org/ soft/view-Photom.html

14. Tropea K., Christou H. Current Pharmacologic approaches for prevention and treatment of bronchopulmonary dysplasia. Int. J. Pediatr. 2012. Doi:10.1155/2012/598606.

15. Nagata K., Iwasaki Y., Yamada T. et al. Overexpression of manganese superoxide dismutase by $\mathrm{N}$-acetylcysteine in hyperoxic lung injury. Respir.Med. 2007; 101 (4): 800-807.

16. Kolleck I., Sinha P., Rustow B. Vitamin E as an antioxidant of the lung: mechanisms of vitamin E delivery to alveolar type II cells. Am. J. Respir. Crit. Care Med. 2002; 166 (12, Pt 2): S62-S66.

\section{Информация об авторах}

Таганович Анатолий Дмитриевич - д. м. н. профессор, зав. кафедрой биологической химии УО "Белорусский государственный медицинский университет; тел.: (37517) 272-67-64; e-mail: taganovich@bsmu.by Анищенко Светлана Леонидовна - к. м. Н., доцент, врач-патологоанатом, зав. отделом организационно-консультативной работы УЗ "Городское клиническое патологоанатомическое бюро" г. Минска; тел.: (37517) 272-49-63; e-mail: anischenko sl@mail.ru

Котович Ирина Леонидовна - к. м. н., доцент кафедры биологической химии УО "Белорусский государственный медицинский университет; тел.: (37517) 272-67-88; e-mail: kotovichil@bsmu.by

Рутковская Жанна Александровна - к. М. н., доцент кафедры биологической химии УО "Белорусский государственный медицинский уни верситет; тел.: (37517) 272-67-88; e-mail: rutkovskayazh@yandex.ru

Поступила 24.06.13

() Коллектив авторов, 2013 удк 616.24-053.31-001-091.8 